\title{
Illustrating Political Discourse: Comics and the Rohingya Refugee Crisis
}

\author{
Ferth Vandensteen Manaysay ${ }^{1}$ \\ Graduate School of Asia-Pacific Studies, Waseda University, Japan
}

\begin{abstract}
This article explores the possibility of examining a storytelling platform, which has largely been ignored by scholars of visual politics about Southeast Asia: comics. It particularly describes how comics can serve as a discursive mechanism for visual representation within the purview of the Rohingya refugee crisis in the region. Drawing from post-structuralism and visual discourse analysis as the theoretical and methodological basis of the research, the article considers a case of a long-form online comic's engagement with the refugee crisis, with particular attention to the criticisms about Aung San Suu Kyi and the bloody military campaign against the Rohingya minorities in Myanmar. By specifically looking into the text-image discourses and inter-textual components of the comics, this article attempts to demonstrate that the ability of comics to "speak" politics is still dependent on international news sources and wider debates, which shape the ways in which the comic artists are able to frame their work. In this case, the use of comics as a story-telling platform, however, also suggests the agency of refugees to be portrayed as political-security actors. Although the article generally focuses on the case of the Rohingya refugee crisis, it also draws attention to the contention that scholars of Southeast Asian visual politics can most profitably engage with other regional issues by turning their attention to the dynamic role of comics as an alternative medium and source of data towards the analysis of threat construction and political-security discourse about Southeast Asia.
\end{abstract}

Keywords: Comics, Post-structuralism, Visual discourse analysis, Rohingya refugee crisis, Southeast Asia

\section{Introduction}

Images have recently emerged in popularity as part of the discursive toolkits of scholars from such disciplines as international security studies, political sociology, and communication studies. In particular, comics has been regarded as one of the most useful sources of data in the visual analysis of social and political phenomena due to the medium's ability to evoke emotions and meanings beyond national and linguistic boundaries (Sani, et. al, 2012). An increasing number of scholars have consequently fulfilled the theoretical and methodological promises of the medium of comics, for instance, in demonstrating in interpretive analyses its relevance on such complex issues as the ethical dimensions of the Bosnian War (Hansen, 2017), Australia's policies of detaining asylum seekers (Humphrey,

\footnotetext{
${ }^{1}$ Corresponding e-mail: ferthmanaysay@toki.waseda.jp.
} 
2018), and the geopolitics of the Cheonan navy vessel sinking in South Korea (Shim, 2017). Although some scholars have analyzed the narrative capability of comics within the broader social and political discourse, there is still a need to examine the ways in which this visual storytelling platform is able to make sense of issues across different meanings and contexts. This article tries to contribute in filling this academic void by turning to Southeast Asia where comics have mostly been ignored as an instrument in examining the discursive and visual representation of the various socio-political actors in and issues confronting the region.

To illustrate this point, the focus of this article is on the case of the visual representation of one of the most pressing regional problems facing Southeast Asia: the Rohingya refugee crisis. The Rohingya people are Muslim minority group living in Rakhine, a state west of Myanmar. In 2015, thousands of Rohingya people fled Myanmar by sea to neighboring countries, making the international media dub them the 'boat people' (National Post, 2015; Murdoch, 2017). By drawing from post-structuralism and visual discourse analysis as the theoretical and methodological frameworks of analysis, this article critically examines the role of comics as a discursive mechanism for visual representation concerning the Rohingya refugee crisis in the Southeast Asian region.

This article intends to meaningfully contribute to the use of images in political analysis by providing a case study of the representation of the Rohingya refugee crisis through an online comic from the award-nominated journalist Erik Thurman, an artist who specializes in long-form comics journalism and nonfiction comics about current events. Specifically, the comic entitled Myanmar's Rohingya Refugees narrates Aung San Suu Kyi's rise as Myanmar's democracy icon, juxtaposing her heroic image with her controversial views regarding the Rohingya refugee crisis (Thurman, 2016). The comic was published at The Nib, a daily comics publication that is part of First Look Media-an American media organization focused on 'independent journalism' (The Nib, n.d.; First Look Media, n.d.). The Nib publishes political cartoons, journalism, essays and memoir about current issues in comic form. Many of the artists who contribute to The Nib have been nominated and won various 
international awards for their work. It mainly explores the political-security discourses about the refugee crisis and the defining features of and core messages about the refugees within the texts and images.

In Southeast Asia, the pressures from the international organizations and civil society groups have prompted several countries in the region to recognize their 'responsibility to protect' these refugees (Kneebone, 2016). Some of the fascinating alternative sources of information, which accompanied the call of the international community to address the migrants' concerns, came from images and materials from photojournalists, cartoonists, and filmmakers who documented the everyday sufferings of the refugees. A photojournalist from the Time Magazine, for example, chronicled the heart-wrenching stories of despair and daily struggles of the refugees for food, water, and shelter (Frayer, 2017). Such images have often gone viral in the social media and even inspired a series of movement in solidarity with the refugees, which took place across such major cities in Asia as Kuala Lumpur, Jakarta, Manila, Dhaka, Bangkok, and Hong Kong (Ahmed \& Griffiths, 2018).
While these different images have also drawn some scholars to look into the visual representation and media framing of the refugees, political comics as a visual storytelling platform deserves a closer look as it may shed a light into the contending perspectives of this regional crisis (Brooten, Ashraf \& Akinro, 2015; Yeung \& Lenette, 2018).

An examination of Thurman's comic on the Rohingya refugee crisis suggests that the portrayal of refugees varies in terms of their representation and interpretation. The comic presents contrasting values across its panels, from criticisms towards Aung San Suu Kyi to the irony between Buddhism's portrayal as a peaceful religion and the Buddhist monks' violent attitude towards the Rohingya minority. Despite the comic's ability to show the complexity of the crisis, this paper argues that the ability of political cartoons-such as Thurman's work-to 'speak' certain political realities still depend on international news sources and wider debates, which shape the ways in which cartoonists are able to frame their work. This also shows the manner comic artists are able to engage in 'visual securitization' (Hansen, 2018) by highlighting the agency of non-state actors. While this article focuses on 
the Rohingya refugee crisis, it contends that scholars of Southeast Asian visual politics can most profitably engage such imperative issues as the regional refugee crisis by turning their attention to the role of comics as a medium in the construction of political-security discourse (Hansen, 2017).

This article is divided into four parts. Firstly, the article makes reference to comics within the extant literature about Southeast Asia. Secondly, the paper draws from existing studies about post-structuralism and visual discourse analysis to provide a theoretical framework and methodology for the study. Thirdly, the paper engages with a case study of the Rohingya refugee crisis. Embedded in the discussion are the different regional and national responses in Southeast Asia. It then closes by raising the study's contributions and agendas for further research on comics in the region.

Comics and Political Discourse in Southeast Asia

Cartoon arts have been slowly gaining popularity among scholars on Southeast Asian visual politics. Yet, there has been little attempt to analyze them from theoretical, methodological, and empirical standpoints. Since Benedict Anderson's (1990) seminal study on Indonesian political communication published in 1973, there has been a limited number of scholarly works which employed comics and cartoons in the context of the political contestations and discourses in Southeast Asia. While some scholars in the region have performed discourse and content analysis across different sources of popular culture materials and made references to the different political, historical, and sociological strands of literature (Berndt, 2014; Chua, 2014), comics has generally escaped scholars' attention. This warrants a deeper conversation on the potential of this storytelling tool to offer novel empirical, theoretical, and methodological insights for the scholars of Southeast Asian visual politics.

The extant literature on comics and politics in Southeast Asia has been productively traced to the classical works which predate the internet. In his fascinating edited volume, Southeast Asian Cartoon Art, political communications scholar John Lent (2014) weaves together an overview of sequential art from the different countries in Southeast Asia. This volume 
appears to be the first and only work to comprehensively deal with the historical origins of comics in the region.

Divided into eight chapters and two sections, Lent's volume looks into the historical and contemporary overviews of comics in Southeast Asia, as well as the salient socio-cultural and political issues accompanying them. The book allots five chapters to provide a historical background of comics in Cambodia, Indonesia, the Philippines, Thailand, and Vietnam. The remaining three chapters, meanwhile, look into the social, cultural, and political aspects of comic art in Singapore, Myanmar, and Malaysia. The volume draws from hundreds of interviews with the creators and readers of some of the most influential cartoons in the region. The collection is notable for bringing together a number of content analysis on the under-documented pieces of comic work in the region.

Lent's main agenda is to highlight the perspectives of the artistic communities, including creators who were put behind bars because of their decision to use comics as a medium to convey their political messages. Most notably, Lisa Brooten's (2014) captivating chapter, Political Cartoons and Burma's Transnational Public Sphere, examines the recent events of the Saffron Revolution and Cyclone Nargis from the perspectives of political. She argues that political cartoons have significantly contributed to Myanmar's growing transnational public sphere and political opposition. Brooten's chapter, along with the other parts of the book, however, appears to merely provide an incomplete representation of the social and political accounts of comics and cartoon art in Southeast Asia. The chapter on Myanmar, for instance, falls short in terms of justifying the selection of cartoons and the events, which mainly take into account the author's shortcoming in her analysis of the country's evolving public sphere.

Recent scholarship on comics has also been gradually growing in the region as evidenced by the significant contributions in the special issue of Kyoto Review of Southeast Asia's Comics in Southeast Asia, which brings together five articles about the social and political significance of comics in the region (Berndt, 2014). This special issue attempts to move away from Japanese, North American, and Western European cartoon scholarship by focusing on the diversity of Southeast Asian comics, 
which range from autobiographical narratives, graphic diaries and essayistic blog entries to education-oriented productions and entertaining fiction. In her article, Jaqueline Berndt (2014) makes an interesting observation about comic studies in the Southeast Asian region whereby comics no longer fall into genres that are divided along the cultural lines, such as "Japanese," "Indonesian" or "Vietnamese," but rather characterized by various forays into what may be called fusion style.

Karl Ian Uy Cheng Chua's (2014) article on the Philippine comics in the special issue traces the educational role of comics in the country. He notes, for instance, that educational comics have started to tackle social, political, and historical issues about the country, including the stories about the Filipino war-time heroes like Jose Rizal and Andres Bonifacio, and the personal experiences of the Filipino migranthousewives during the 2011 Great East Japan Earthquake and Tsunami. He argues that although these comics have not been intended to be historically accurate it is important to note that these bodies of work have made Philippines' history more accessible to the public.
Nguyen Hong Phuc (2014) echoes a similar tone in his article about the development of comics in Vietnam. Phuc contends that historical facts and national heroes have been reintroduced in Vietnam using comics. He notes, for example, that the Vietnamese government has used comics to clarify the country's position regarding the South China Sea dispute. In many ways, however, he also underscores that "Vietnamese comics are not afforded the leeway to stabilize and find their own equilibrium in contemporary Vietnamese culture" (Phuc, 2014). Meanwhile, autobiographical tales have been the main trend in Singapore. Lim Cheng Tju (2014) demonstrates that 'personal stories' have also dominated Singapore's comics industry due to the curtailment of political venues of expression in the city-state.

While Filipino, Vietnamese and Singaporean comics are influenced by local history and events, Febriani Sihombing (2014) shows how Indonesian comics have largely been influenced by foreign elements to make local publishers more competitive in the national market vis-à-vis international comic creators. Sihombing (2014) highlights that the notion of gaya (i.e. 
foreign styles) has given birth to a sense of geopolitical classification among the comics in the country, which means that there is a distinction in terms of the styles of Indonesian creators in relation to the aesthetics of the works of international comic artists.

Although the abovementioned works have been hugely informative in terms of providing unique insights into one of the least-documented regions of comic creation, there has been a limited attempt from the part of Southeast Asian comics scholars to treat the compressed and dynamic relationship between texts and images within the medium as a distinct analytical instrument in studying the visual representation of the different social and political issues confronting the region.

Based on the above discussion, there are three main reasons why comics should be more deeply incorporated within the research agendas of scholars of Southeast Asian Studies. The first reason relates to the manner by which comics and their creators are able to provide a space for the centrality of the region in global issues. Historically, comics is one of the few forms of social and political expressions in which issues of importance to the international community have been discussed more succinctly and creatively. This includes sensitive political issues such as the plights of the Cambodians during the Khmer Rouge regime, the stories of the Philippine and Vietnamese national heroes, and the experiences of the Rohingya refugees in Myanmar.

The second reason hinges on the idea that political cartoons and comics may represent critical and marginal discourses about Southeast Asia, which may not be present in the mainstream media. This is particularly the case for some countries in the region with authoritarian experiences. The development of comics, for example, has been dependent on the type of government in power. Comic's political dimension is elaborated in Lent's (2007) narration of the experiences of cartoonists from Southeast Asia who had to use subtle means to bring their political messages to the public. In fact, some political cartoonists have resorted to self-censorship because of the oligarchic control of major newspapers, such as in the Philippines, while others had to leave their own countries and go into exile, such as Myanmar, to publish their politically charged work (Lent, 2014). 
The third reason for bringing comics into the study of Southeast Asia is precisely because the medium can advance new questions for further research in the field. Globally, scholarship on comics has been dominated by the geo-political and cultural issues about North America, Western Europe, and Japan (Berndt, 2014), and not much has been written on comics about Southeast Asia. In terms of the theoretical and conceptual dimension of the issue at hand, it is important to dig deeper into the potential of comic studies in studying socio-political issues in Southeast Asia.

Comics, Post-Structuralism, and Visual Discourse Analysis

Comic scholars have mostly focused on the relationship between images and texts as the object of their studies. International security scholar Lene Hansen's (2017) poststructuralist approach, for example, draws from cultural-sociological and semiotic theories to make sense of the connection between comics and international politics. Hansen puts forth a three-step theoretical framework on the practice, discourse, and intertextuality of comics. She engages with the following components: (1) cultural capital and comics practices; (2) the text-image discourse of comics; and (3) an inter-textual approach to the study of comics.

In terms of the cultural capital and comics practices, she posits that the comics' institutions of production, circulation, and consumption needs to be considered as they are important for understanding the societal status of the medium and their historicity (Hansen, 2017). In this sense, Hansen also notes that the comic as an object or medium itself does not guarantee cultural legitimacy. Rather, cultural legitimacy is socially produced through and evidenced by critics, collectors and academics engaged with the comic (Hansen, 2017).

With regard to the text-image discourse of comics, Hansen argues that the discourse between text and image is dependent on the meanings behind not only those contents, which are concretely included as words and pictures, but also by those that are excluded in the comics. She refers to these as the gutter or the blank space between panels that are based on the interpretations of the readers. This means that comic reading is 
largely an interpretive method of visual storytelling.

Hansen (2017) posits that for a comic to be able to tell a narrative its readers has to be able to continuously follow one image to the next and 'something' needs to be filled in between to fulfill that continuity. The gutter becomes the space that the artist assumed the reader can most fill in, and yet, it might also be a demarcation of the limit to what the artist can represent. In the latter usage, the gutter is not something that connects reading, but where a visualtextual discourse cannot fully account for the full extent of the event portrayed in the comic. This means that scholars who are looking into comics should ask not only what is depicted in the comics' images and what are stated through its text, but also what takes place between the panels.

The inter-textual approach, meanwhile, depends on how the texts and images within comics make reference to events and practices related to the wider discourses within the broader public sphere. From this perspective, she argues that 'comics intertextuality' depends on a number of selection criteria including the number of comics, the impact on foreign policymaking and diplomacy, the circulation, the presence of marginal or critical discourse, the cultural legitimacy, style and genre, and the ability of the content to engage towards theoretical and conceptual discussions (Hansen, 2017). Consequently, for this research, the use of comics adheres to Hansen's preference for the twin-objectives of visual and textual analysis. In this sense, comics-particularly political comicscan be treated as a visual and textual medium, which is compatible with the interpretive methods within discourse analytical approaches.

Intertextuality in the study of comics has been well-taken into account in several works. David Shim (2017), for example, presents a highly relevant work on political comics in his geopolitical analysis of the Cheonan, a navy vessel that was purportedly sunk by a North Korean torpedo. Shim explores the dramatic structures and rhetorical devices of a comic series, which was published by the South Korean Ministry of National Defense. His analysis draws from a plot structure or narrative arc similar to a film or a play, which is composed of the 'exposition', 'rising action', 'climax', 'falling action', and 'dénouement,' to make sense of the 
critical representation of the purported truth behind the sinking of the said navy vessel. In the 'exposition,' the artist introduces the comic's main characters to the readers and explains what the story is about (MacDonald, Dodds \& Hughes, 2010). Meanwhile, the 'rising action' part of the narrative arc serves as the narrative preparation of the story's 'climax,' or main conflict of the story which shakes up the status quo (Shim, 2017). Following the climax, the 'falling action' part of the narrative resolves the main problem in the story. Finally, in the dénouement, the story concludes with a renewed status quo. Shim's interpretive reading of the geo-political spaces of the said incident also provides a vital model for this research.

Representation of Myanmar's Democracy Icon, Genocide, and the Refugee Crisis

Building upon the post-structuralist perspectives of discourse analysis presented above, this section applies them to analyze Erik Thurman's comic on Myanmar's Rohingya refugee crisis. Furthermore, the structure of this section will follow a narrative arc similar to Shim's (2017) work on the South Korean comic analysis, which is composed of the 'exposition', 'rising action', 'climax', 'falling action', and 'dénouement'.

As regards the cultural capital and comic practices, the comics' institutions of production, circulation, and consumption needs to be considered to understand the medium better. Thurman's comics have appeared on popular print and digital publications such as The Nib, The Guardian, Fusion, Medium, First Look Media, The Melton Prior Institute, Oxford University, University of the West of England, Mingjing News, and World Comics India, among many others. Aside from his depicted scenes about the mass genocide in Myanmar, according to his website, he has covered a wide range of issues, including the political kidnappings of university students in the Philippines, the economic inequality and protests in Seoul, the nuclear war threats of American president Donald Trump against North Korea, and the modern-day slavery in Qatar and India. His most notable work is perhaps his graphic memoir trilogy, The American Immigrant, which earned him a nomination for a Reportager Award.

Erik Thurman's full-colored comic seems to be sketched in a standard 
format of printed work of art, which tries to maintain a balance between images and texts to keep the attention of the reader towards the illustration. His work appears to be a product of gouache paint, which offers richer, thicker, and darker shades than acrylic or water colored designs and illustrations. Although his illustration departs from popular Japanese-style manga, which tends to highlight childlike facial features, Thurman's iconography, nevertheless, heavily relies on expressive character designs. In this sense, he employs both verbal and non-verbal forms of communication to set the tone of his characters. As such, this style has generally been suitable for the scope of Thurman's work, which has focused on non-fiction comics about current socio-political issues.

In terms of the particular textimage discourse of comics, the main conflict that the Myanmar's Rohinfya Refugee comic tries to pose. The main conflict that the Myanmar's Rohingya Refugees comic tries to pose for the readers is how Aung San Suu Kyi, a national hero, could ignore her country's refugee crisis despite the fact that the

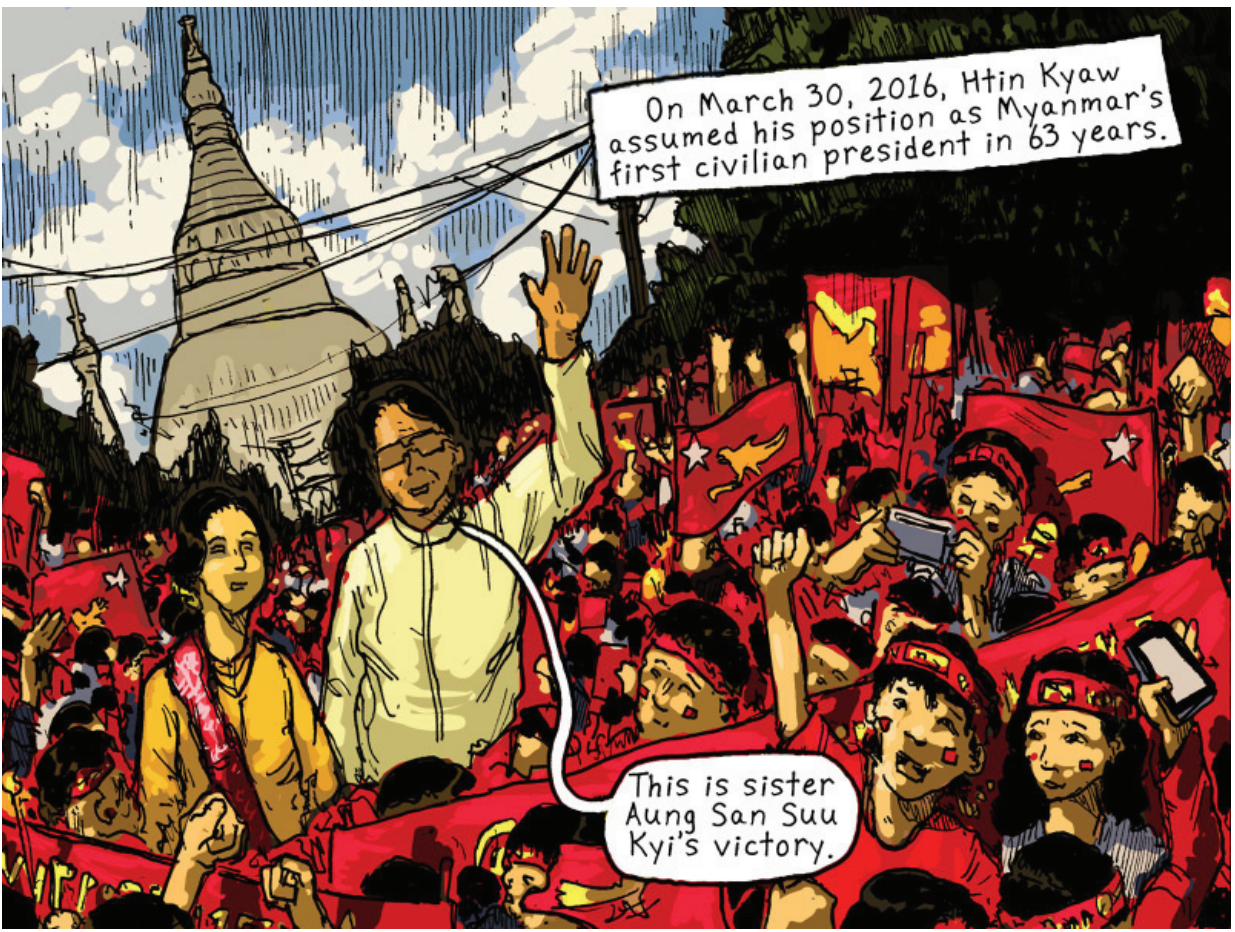

Figure 1. Aung San Suu Kyi and and Htin Kyaw's rise to power in Myanmar. Thurman, Myanmar's Rohingya Refugees. (Thurman, 2016) 
issue has gained widespread attention from the international community. The 'exposition' of the story sets out with the rise of Htin Kyaw, who was elected on March 30, 2016, as the first civilian president to hold the office since the 1962 coup d'état. Kyaw has been largely considered as Suu Kyi's most important ally and trusted friend after the latter appointed him as the candidate of the National League for Democracy (NLD) party, which has allowed Suu Kyi to wield political influence over Myanmar (Ellis-Petersen \& Arnold, 2018). The exposition image in the comic features a significant number of protesters holding NLD's red-colored party flag as a sign of support for Kyaw and Suu Kyi (see Figure 1). Kyaw's victory was mostly seen as a deal to represent Suu Kyi in the government.

The narrative then looks back into Suu Kyi's humble beginnings when she became an international symbol of democracy by the use of 'quotes' to reenact an iconic photograph. As noted by Lene Hansen (2015), the use of quotes to re-enact iconic photographs could bring a sense of historical authenticity into the narrative. In Thurman's comic, the readers can see a re-enactment (see Figure 2) of Suu Kyi's photograph (see
Figure 3) with her husband Michael Aris and her son Alexander, who are both British citizens. Suu Kyi entered politics to fight for Burmese democratization and helped found the NLD on 1988, but was put under house arrest the next year. She became an icon for democracy during her fifteen-year house arrest under the military rule. Although the constitution forbids the Nobel-laureate from running as Myanmar's president due to her having children with foreign citizenship, Suu Kyi has been considered as the state counselor or the country's de facto leader. In Thurman's comic in particular, the quote humanizes and provides a dose of historical accuracy by featuring the personal lives and 'untold love story' of Suu Kyi and Aris (Frayn, 2011).

Aside of using quotes as a narrative tool, Thurman also incorporated the separation of image frames through white blank spaces, which was earlier identified as the gutter. In this case, the gutter serves as an instrument to arrange the panels in a sequential order. Moreover, the historical appeal of the narrative provides the author with some leeway to make a few flashbacks in the story as seen in the reenactment of photograph mentioned above. 
The story then moves on with a promise from Suu Kyi that Kyaw's victory symbolizes a new age of 'true democracy' for Myanmar's vast minority demographic during NLD's inauguration. In her portrayed speech, Suu Kyi proclaims: "We cannot build lasting peace without national reconciliation. Now, we are ready to lead the peace process because we have the power invested in the mandate given to us by the people and ethnic minorities." This is another strategy of the comic artist to insert a real quotation, which Suu Kyi said during her keynote address in front of ethnic armed groups on January 2016. For many years, the ethnic armed groups have resisted the Burmese military government. Her address outlined her vision of a federal future and peace process for ethnic rebels who have experienced decadeslong repression under the military regime (The Strait Times, 2016). The peace process has included issues of separatism and land ownership, which have displaced tens of thousands of people. Suu Kyi's promise to the ethnic rebels bridges the 'exposition' with the 'rising action' part of the narrative.

The second segment of the narrative, which could be considered as the 'rising action', meanwhile, paints Myanmar as a predominantly, poverty-

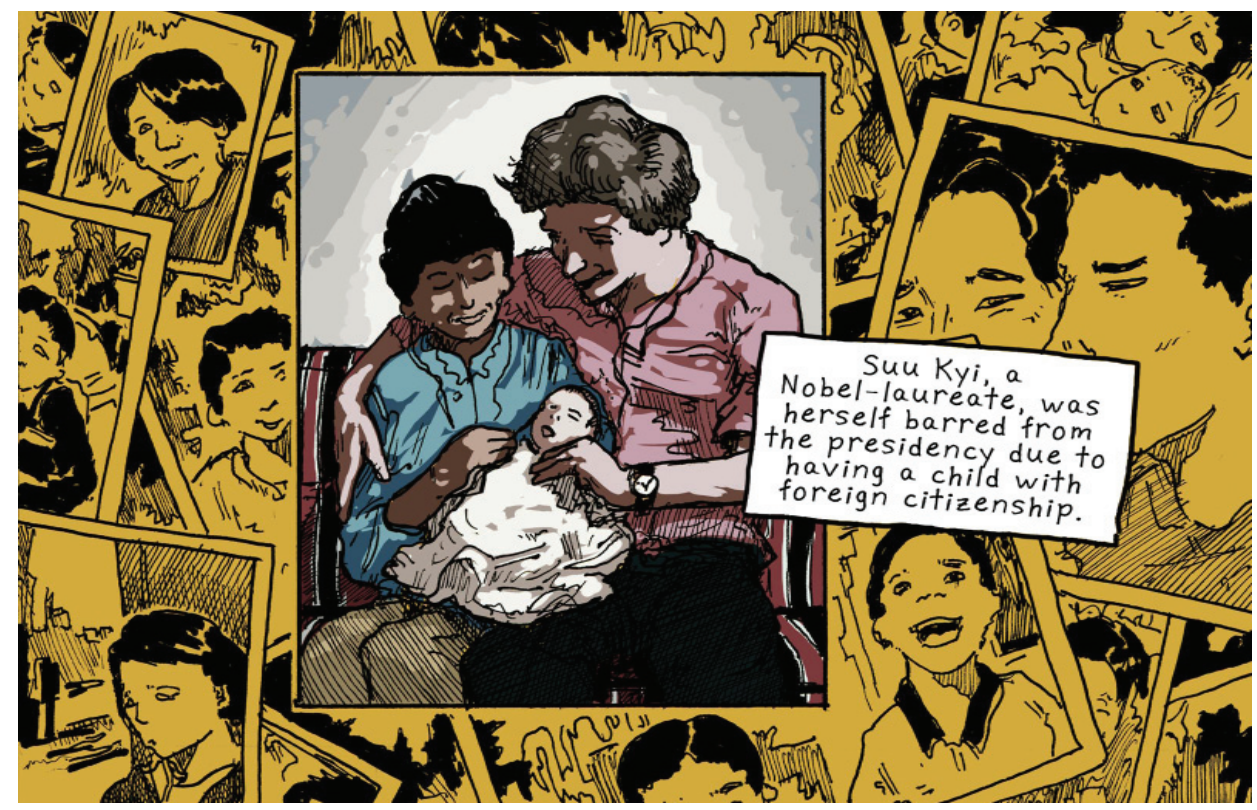

Figure 2. Aung San Suu Kyi and Michael Aris with their first-born son Alexander. Thurman, Myanmar's Rohingya Refugees. (Thurman, 2016) 
stricken Buddhist country with about 132 officially-recognized minorities, including the highly persecuted Rohingya Muslim minority in the western Rakhine state. The comic artist provides a historical background of the refugee crisis. Although the media has largely portrayed the crisis as a much more recent phenomenon, the comic revealed to the readers that, in reality, the ethnic cleansing in this part of Burma has been going on since 1947. This background serves as the preparation for the story's climax about Suu Kyi's indifferent statements about the Rohingya Muslim minority despite her promise for peace with the minorities. In this particular section, the comic tries to paint the refugees as the 'victim' of a repressive Burmese government, which has labeled them as illegal 'Bengali' residents because of the darker color of their skin and due to their perceived migrant identities as well.

It is worth noting that the comic is able to convey the complexities of the Rohingya refugee crisis by weaving it in the narrative. For instance, the comic makes a statement that this situation is ironic given that the violence has been perpetuated by Buddhist monks, who were also subjected to repression and disenfranchisement during the authoritarian rule. In Myanmar, the authoritarian regime institutionalized the racist attitudes and stereotypes against the Rakhine Buddhists and the Rohingya minority. The story then follows the first and most deadly riots and clashes between the Rakhine Buddhists and Rohingya Muslims, which happened in June 2012. The incident was sparked by the rape and murder of a Buddhist girl by three Muslim men. A chain of violent episodes soon followed the initial riots. This includes the clash between the Buddhist and Muslims in Central Myanmar on March 2013. Following that clash the Buddhists burned Muslimowned houses and shops in Kanbalu town on August 2013 (BBC, 2013), killed 40 Rohingya men, women, and children in Rakhine state on January 2014, and killed Muslims in Mandalay after social media rumors spread that a Buddhist woman was raped by Muslim men on June 2014 (Agence France-Presse, 2014).

Despite the complexity of the events, the artist manages to present the tension by using images of violence with accompanying texts to give the readers some context to the situation. For instance, the comic sums up the episode of violent incidents by stating 
that "Rakhine state Buddhists retaliated against the Muslim community" which has then led to "a state of emergency after thousands of homes were burned to the ground." The comic also outlined the extent of the violence where hundreds of people were killed, while hundreds of thousands were displaced to neighboring countries. These texts help the readers to follow the narrative while interpreting the images (Hansen, 2017). Nonetheless, despite the artist's effort to show the severity of the migrant crisis, the comic is limited in its ability to present the full extent of the Southeast Asian region's geopolitics.

After mentioning the number of displaced Rohingyans (see Figure 4), the comic's artist moved the narrative to show the refugees' conditions to the readers by framing from a 'narratives from below' perspective. The gutter between these two narrative aspects allows for further exploration for scholars of politics and sociology, particularly in understanding how the displacement caused the refugees such suffering.

As the Rohingyans fled Rakhine, the refugee-hosting governments in the region, such as the Thai, Indonesian, and Malaysian governments, for instance, have responded to the influx of the
Rohingya people in the region based on their existing legal frameworks. The lack of enabling laws to accommodate the refugees has typically intensified the discrimination against the forced migrants from Myanmar. The reaction of the Indonesian, Malaysian, and Thai governments was to deny entry to the migrants. The forced migrants, who mainly fled by boats, were then regarded as the 'boat people'.

In May 2015, thousands of boat people were stranded after the nations surrounding the Andaman Sea turned away the Rohingya-and to a lesser extent those from Bangladesh as wellmigrants who attempted to avoid persecution by extremist Buddhist mobs in Myanmar. The main line of argument of the destination Southeast Asian countries for denying entry for forced migrants from Burma was that the Indonesian, Malaysian, and Thai governments are not signatories to the international conventions on refugees. Aggravating this situation was the fact that government officials claimed their countries did not have sufficient resources to host the refugees.

The influx of the refugees has entailed additional costs for the concerned borders and governments, 
which is why there have been attempts from government officials to securitize the issue and paint the refugees as existential threats that are beyond the means of the state's resources (Mohajan, 2018). For instance, the Indonesian Foreign Ministry spokesperson, Arrmanatha Nasir, claimed that aside of the pressing humanitarian issue, being a rich country, Australia should not ignore the migrant crisis instead of making it the responsibility of other Southeast Asian governments. Furthermore, the Incumbent Thai Prime Minister Prayuth Chan-o-cha also questioned the fairness of putting international pressure on transit countries like Thailand to act on the refugee crisis: "If we take them all in, then anyone who wants to come will come freely. I am asking if Thailand will be able to take care of them all. Where will the budget come from?" (Associated Press, 2012).

In Thailand, the government officials have sent mixed messages in terms of their policy towards the Rohingya refugees. Although Prime Minister Chan-o-cha, for example, has agreed to accept refugees into the Thai borders, the action of his regime has been less than welcoming of the boat migrants. Thailand's 'push-back' policies have been exacerbated by the fact that even those who managed to reach the nation's border were subjected to forced labor, human trafficking, and other forms of abuses (Phasuk, 2017). In fact, the Internal Security Operations Command, which is headed by Prime Minister Chan-o-cha himself, has employed and announced a threestep approach to the refugees who attempt to enter Thailand, which was to intercept Rohingya boats that came too close to Thai coast, to provide supplies for the migrants to further continue their journey to other countries, and lastly to seize boats that managed to land on Thai coast and apprehend their passengers in indefinite detention (National Post, 2015).

Malaysian authorities have also responded to the refugee crisis with a similar tone as their neighbors. Deputy Home Minister Wan Junaidi Jafaar, for example, said that the government of Malaysia must "send the right message" that the Rohingya refugees "are not welcome" in Malaysia (National Post, 2015). "What do you expect us to do? We have been very nice to the people who broke into our border. We have treated them humanely but they cannot be flooding our shores like this," he 
added. An official from Malaysia Prime Minister Department, meanwhile, said refugees are not recognized in Malaysia, equating the migrants to "water" that will "gush and flood" the country and whose presence becomes a security threat by citing the lack of official legal agreements to host these migrants (Arukesamy, 2015).

While the comic cannot fully account the extent of the Southeast Asian geopolitics' complexity, the analysis provided above contextualizes Thurman's comic. The gutter in the comic invites both the readers, and particularly scholars, to understand the complex actors in the narrative. This echoes Hansen's (2017) cultural capital element of comics where she posits that the comic's cultural legitimacy lies upon the scholars engaged with the material itself.

After presenting the mass migration of the displaced Rohingyas and the refugees' conditions as part of the 'narratives from below,' Thurman then proceeds to the 'climax' of the story, which features Suu Kyi's lack of sympathy towards the genocide of the Rohingya Muslim minority in her country. The comic illustrator cites a number of reasons behind Suu Kyi's silence, including the Rohingya minority's lack of right to suffrage and

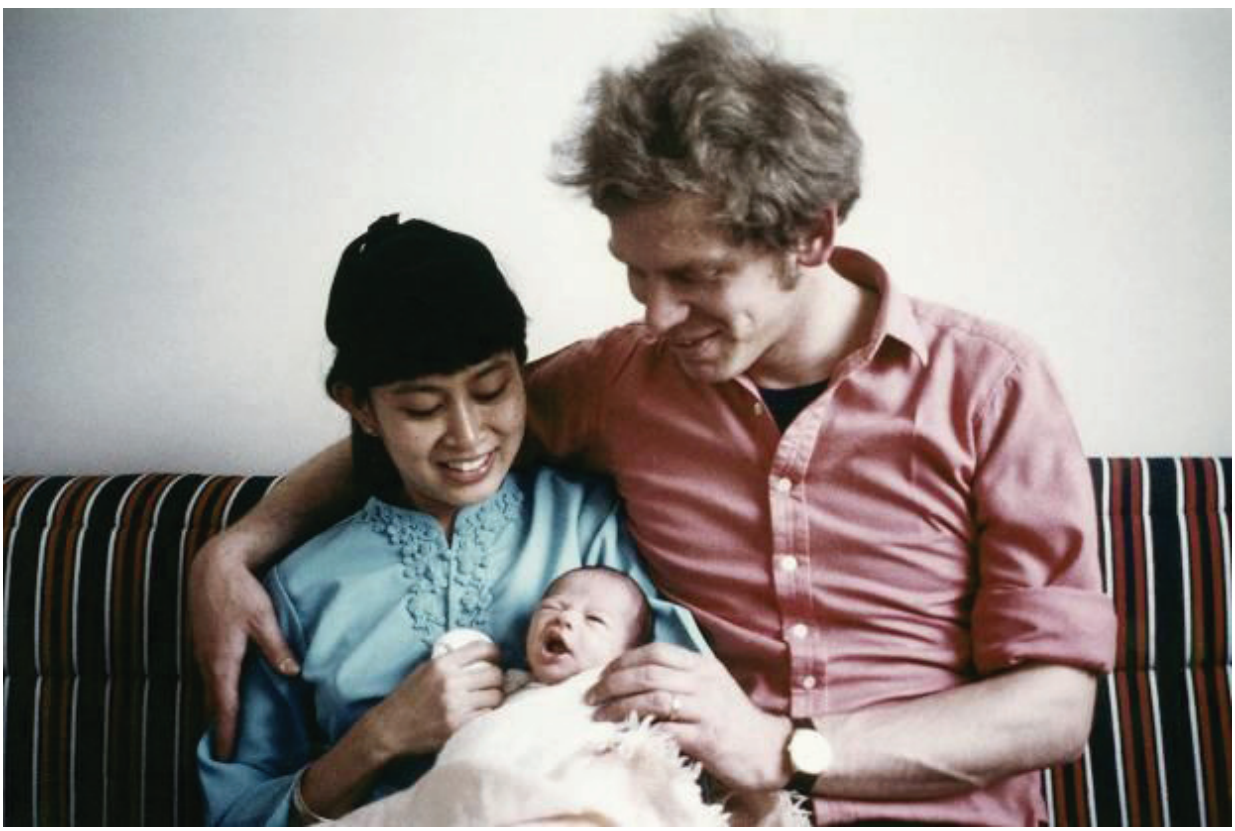

Figure 3. The real photograph of Aung San Suu Kyi with husband Michael Aris and son Alexander. (Aris Family Collection. All rights reserved: Getty Images) 


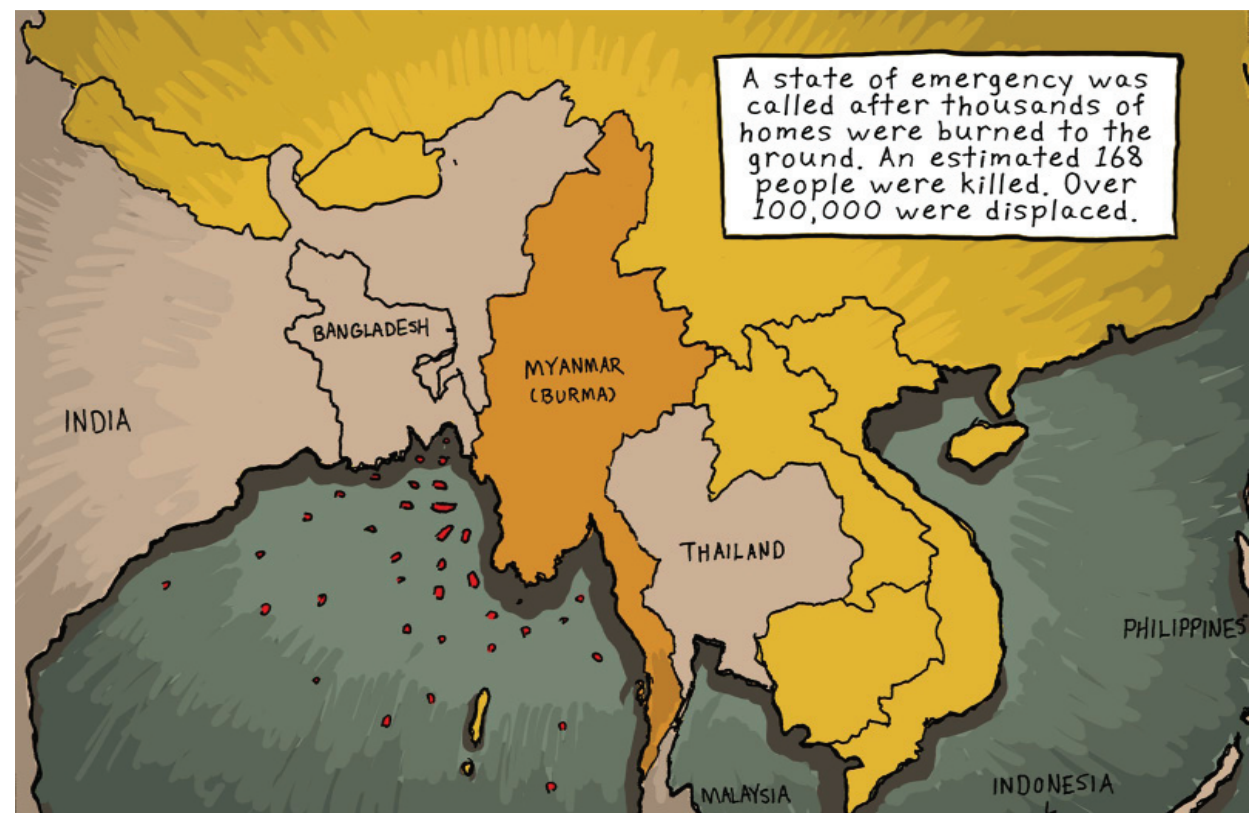

Figure 4. The displaced number of boat migrants have reached beyond 100, 000 people. Thurman, Myanmar's Rohingya Refugees. (Thurman, 2016)

the underrepresentation of Muslims in the Burmese political landscape.

Thurman's personal view seems to be most evident in the statement that "Suu Kyi has no problem with the persecution of the Rohingya." The comic cites the Burmese State Counsellor's viral interview with the British Broadcasting Corporation (BBC), which highlighted one of her initial reactions to the criticisms of human rights organizations regarding her deafening silence about the issue. "I think it's very important that we should not exaggerate problems in the country. We have to make big problems small and small problems disappear," she told the media. She also undermined the humanitarian crisis by merely describing the situation with 'a lot of hostlity' and denying the existence of 'ethnic cleansing' which she claims to be a 'huge icerberg of misinformation' from global civil society groups and humanitarian organizations, including the UN Refugee Agency (Agence France-Presse, 2018). The comic also noted Suu Kyi's attitude towards Muslims by portraying her after one of her interviews where she questioned why she was not informed beforehand about being interviewed by a Muslim. This re-inforces the comic illustrator's earlier inclusion of the discrimination against Muslims as one 
of the reasons behind her indifference towards the Rohingya minority in the country.

Such statements, however, relate to a more existential threat linked to the influx of Rohingya refugees in Southeast Asia: terrorism. The Indonesian government has been particularly cautious about the possibility that the country's far-reaching Islamic extremist networks will recruit Muslim Rohingya refugees. These fears are not unfounded given that the Islamic Defenders Front (FPI) has recently called for volunteers to wage jihad or holy war against the Buddhist majority Myanmar to protect the Muslim Rohingya population. No less than the global terrorist organization Al Qaeda-with links to Indonesia's Jemaah Islamiyah terrorist organization-has released an unofficial call to arms towards their supporters for the "savage" treatment of their Muslim fellows by the Burmese government (Mironova \& Sergatskova, 2017).

The Rohingya refugees have therefore been framed as political, economic, and social security threats. The refugees have been painted as financial burdens, terrorists, and illegal migrants who pose extraordinary problems to the state and society. In this regard, the comic illustrator also employs another important strategy, which is to include the personal narratives of the people on the ground during the refugee crisis. After all, the personal narratives of refugees are often left unsaid and underrepresented in the mainstream media. For the most part, the personal narratives involve the illegal arrests of Rohingya minority and threats from the police to kill their families.

Additionally, the story also provides an image of the government's favorable atittude towards the Bengali Buddhists who fled Myanmar after decades of conflict by inviting and resettling them back to the areas, which were left by the forced eviction of the Rohingya minority (see Figure 5). This attitude further juxtaposes the Suu Kyi government's ignorance towards the Rohingya Muslims, which Thurman shows as he transitions into the 'falling action' part of the narrative.

The fourth narrative segment of 'falling action' provides a backdrop of the critical period and challenge to the Suu Kyi and NLD's leadership following calls to reform the distriminatory 1982 Citizenship Law. Under this law, full citizenship is primarily based on 


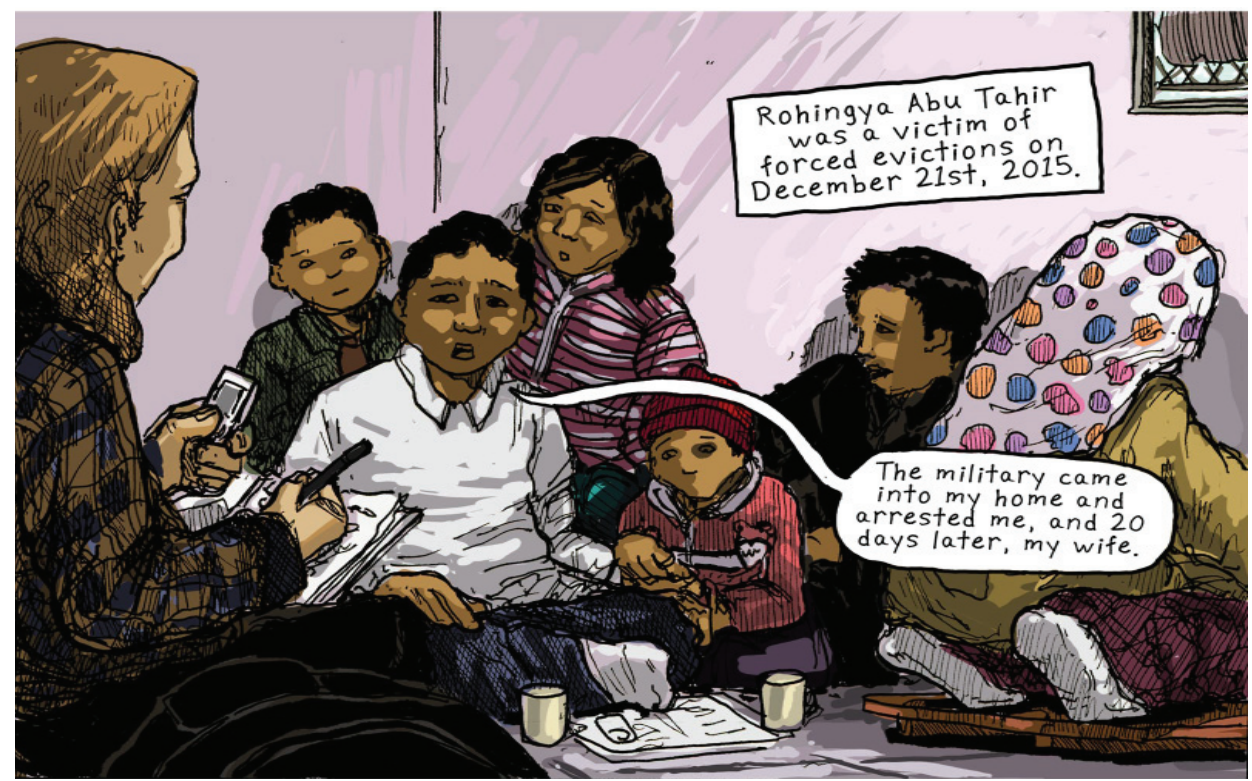

Figure 5. Some details about the forced migrants were excluded from the comic. Thurman, Myanmar's Rohingya Refugees. (Thurman, 2016)

membership of the "national races" who are considered by the State to have settled in Myanmar prior to 1824, the date of first occupation by the British. Despite generations of residence in Myanmar, the Rohingya are not considered to be amongst these official indigenous races and are thus effectively excluded from full citizenship. On May 2016, Myanmar's parliament has voted down the proposal, which would allow more than half the undocumented Muslims in Rakhine and other regions for citizen status. The proposal received 154 votes in favor and 228 against, with seven abstentions from the lower house of the parliament (World Bulletin, 2016).
In response to former U.S. Department of State secretary John Kerry's question about Myanmar's course of action regarding the refugee crisis, Suu Kyi sent a plea to the international community to stop using the term 'Rohingya' in her call for 'space' for her government to address the issue. Suu Kyi argues that the international community should avoid using terms that could "add fuel to the fire" when she was asked about her position regarding the Rohingya refugee crisis.

This segment of the comic culminates with a proposed course of action that Myanmar should follow to be recognized as a legitimate democracy. This includes 


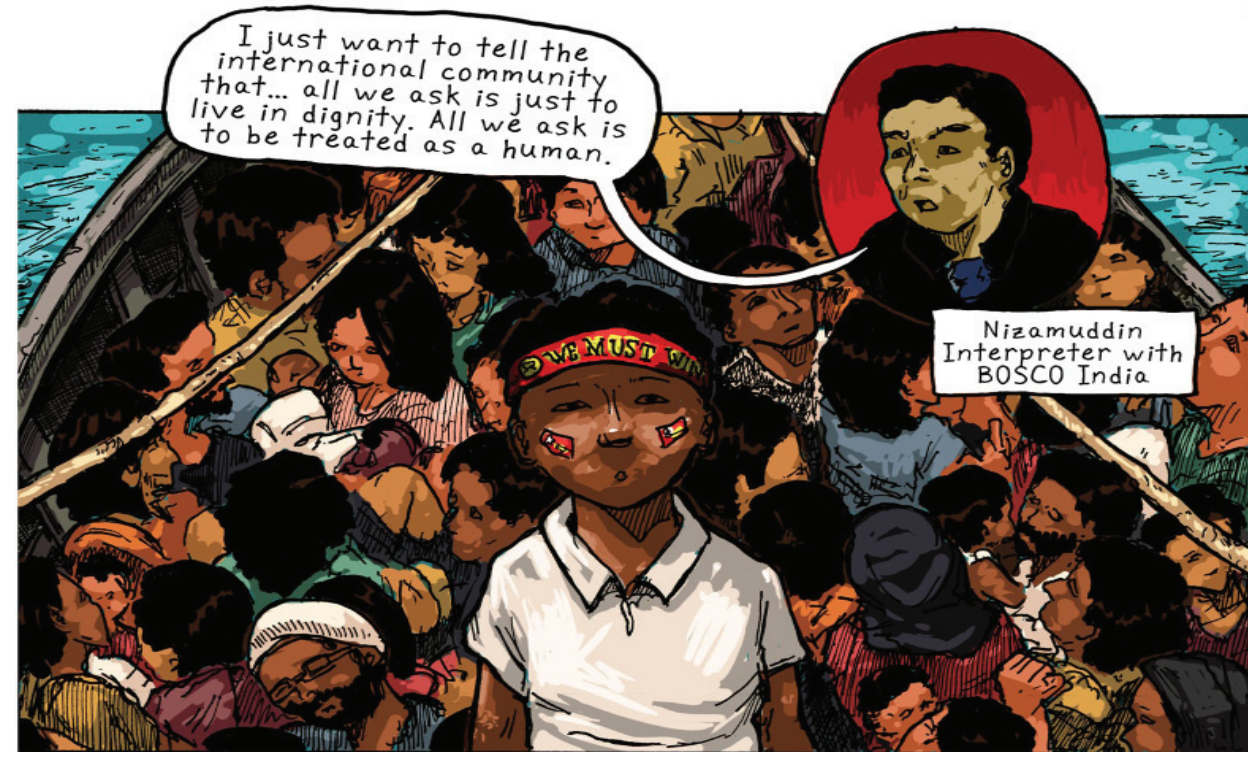

Figure 6. The statements of the refugees are highlighted towards the end of the story. Thurman, Myanmar's Rohingya Refugees. (Thurman, 2016)

the need to act upon hate-speech and extremism, ensure humanitatian access, reform or repeal the 1982 Citizenship Law, and demonstrate justice and accountability by investigating the human rights violations against the Rohingya in Rakhine State. The author cites European Union as one of the main international actors, which has pressured Myanmar to end violence against the Rohingya minority, although there are also agreements from the neighboring countries regarding the refugee crisis. Additionally, at the regional level, the response of the Association of Southeast Asian Nations (ASEAN), meanwhile, has been quite limited because of the difficulty to reconcile the regional norms such as the principle of non-interference (Jati, 2017).

Indeed, as the refugee crisis went on, "denials of responsibility were expressed by states in the regionwith calls for the 'richer' countries like Australia to settle the refugees-and continued push backs of boats carrying the Rohingya people by Indonesia, Thailand and Malaysia" (Kneebone, 2016, p. 161). Despite the membership of many Southeast Asian countries in the Bali Process - a forum for policy dialogue, information sharing and practical cooperation to address 
people smuggling, trafficking in persons and related transnational crimes - it was criticized for the inability of the government leaders to come up with decisive solutions to resolve the refugee crisis. The Bali Process, at the very least, has succeeded in terms of promoting protection at the regional level. The actions and protests of international civil society groups, in addition, have been instrumental in pushing for a more consolidated action plan in the region. In May 2015, for example, Malaysia, Indonesia, and Thailand have agreed to find a solution to the migrant crisis and its "serious impact" on the affected countries' national security. Another joint statement of 114 international groups also framed the crisis as a human rights issue (The Daily Star, 2017). In many ways, these meetings and calls for action have provided openings to widen the humanitarian protection discourse in the region.

In the final section or the 'denouement,' Thurman presents the agency of the Rohingya refugees. In the last panels, Thurman ends with the refugees' perspectives (see Figure 6). Through 'visual securitization' (Hansen, 2018), the artist empowers them by highlighting their role in the refugee crisis and how they shape the way the international community has perceived the crisis. As mentioned above, the refugees have often been 'securitized' (Buzan, Wæver, \& de Wilde, 1998) and reduced into societal, political, security, and economic threats by neighboring state actors. The author's decision to end with statements from the refugees, however, indicates that the narration of security is not just limited to the state, but also to the migrants themselves. This resonates with Faye Donnelly's (2017) argument that there should be a distinction among the existential threats and referent objects in the securitization process.

Donnelly posits that this distinction moves on from simply framing migrants as 'threats', which is a damaging discourse that has attempted to recast both refugees and asylum-seekers as a danger rather than as people who are threatened. Thurman's attempt to instill a sense of agency in his comic resonates with the larger picture of the Rohingyans' desire to control their own narrative as political-security actors. For instance, the presence of the New York-based World Rohingya Organization, shows that the refugees and humanitarian organizations may 
collaborate to assume the role of the political-security actors.

While presenting an alternative perspective of the crisis by showing the humane side of the event, the comic also briefly exposed another important actor at play in this refugee crisis, which are humanitarian organizations. Jocelyn Vaughn (2009) explains, for instance, that humanitarian organizations who support refugees have attempted to securitize refugees in order to make the case for the 'right to survive' of the referent objects. In this comic, the statements of the refugees particularly demonstrate that the international community serves as their audience, while the existential threat emanates from the migrants' country of origin, which in this case is Myanmar.

While at the beginning of the comic the plights of the refugees were presented through the repressive role of the Myanmar's government against the Rohingya minority, this top-down perspective is replaced by a bottom-up perspective. The comic's final panel (see Figure 6) reveals a sense of 'politics from below' by reinforcing the refugees' succinct message to the public. The comic also culminates the story with the note that the refugees have the support of the international community. In reality, however, the situation of the refugees remains precarious. Although the pressures from international organizations and civil society groups have prompted most countries in Southeast Asia to recognize their 'responsibility to protect' these refugees, there are still many challenges ahead confronting them especially in terms of their social, political, and economic well-being within the confines of their host communities.

Thurman's comic has consequently shown how drawn visual representations of marginalized group of people coincide with the discursive and narrative elements of the story. In this case, the comic provided an illustration of the manner texts and images are able to represent the different issues surrounding the Rohingya refugee crisis. These include the different portrayals of the characters and the meaningsmaking processes behind the 'visualities' embedded in the comic (Shim, 2017). Beyond the narrative structure (exposition, rising action, climax, falling action, and de'nouement), the comic's intertextuality connotes the ability of the illustrator to bring forth the 'silent subject' (Hansen, 2017) about the plights of the Rohingya refugees. More 
concretely, however, there are issues worthy of further pursuit in relation to the study of Southeast Asia.

\section{Conclusion}

A comic-based visual discourse analysis offers an analytical mechanism for scholars to understand Southeast Asian politics. In particular, this article looked at how comics can provide texts and images, which constitute a novel way of examining the visuality and intertextuality of the Rohingya refugee crisis. This research explored how Erik Thurman portrayed the political discourses about the Rohingya refugee crisis in his comic. Furthermore, beyond the texts and images, this paper has discussed how this contentious political comic has represented some of the most pertinent political and security discourses surrounding the Rohingya refugee crisis.

Despite the comic's ability to sum up the complexity of the Rohingya refugee crisis and most political actors involved in it, this representation is certainly a simplified picture of the full extent of the issue. Thus, a robust framework of analysis is needed to understand the cultural production of the comic, its texts and images discourse, and the context of the material through inter-textual analysis (Hansen, 2007) in tandem with pluralistic methodologies and epistemologies (Hansen, 2018). Nonetheless, scholars attempting to adopt a similar comic analysis method to study regional geopolitics may encounter a selection bias by selecting only a small number of comics to analyze.

One of the main methodological problems encountered in this research can be attributed to fact that this article's analysis is based on a single comic from a foreign artist due to the lack of available long-form comics on the crisis. There is a limited amount of meaningful visual work on the refugee crisis based on the initial research for relevant comics. The decision to use a single case also avoids sweeping comparisons between comics and their broader visualtextual discourses. Although there are numerous political cartoons about the refugee crisis (e.g. newspapers), this article has intentionally used Thurman's work because it is one of the only available long-form-instead of shortform editorial cartoons-comics on the issue, which is critical to the main goal of the study to meaningfully weave the relationship between texts and images. 
The use of a foreign-authored work also gives the research an opportunity to argue about the centrality of Southeast Asia on global political issues. In this regard, it also acknowledges that some questions and issues may further be raised about the production, circulation, and consumption of the comic examined in this article.

Aside from its limitations as an analytical tool, scholars who intend to conduct similar studies on Southeast Asian comics are faced by the issue of the relatively scarce number of Englishlanguage resources. This particular study faced this issue as well, and this is most likely due to the fact that the Rohingya refugee crisis is still a developing issue and it is expected that more comic works will come out in the future. Additionally, scholars who intend to study comics in other countries in the Southeast Asian region may face different political challenges. For instance, Myanmar's state censorship also affects the availability of online comics about the refugee crisis or that in Thailand criticisms towards the King is punishable. There is, however, a need to further scrutinize comics which are written in Southeast Asian languages as they may reflect contexts and peculiarities which foreign authors cannot capture in their work.

The main contribution of this article to the current scholarship on Southeast Asian visual politics, nevertheless, has been its theoretical and conceptual reflection on the specificity of comics as a medium based on the selected example about some of the critical issues confronting the Rohingya refugee crisis. In particular, the article demonstrated the complicity of the medium in speaking and performing the 'political' through the analysis of the narratives behind the Rohingya refugee crisis. While several scholars have already explored the process of drawing and interpreting meanings from comics, most of the existing literature have been limited to North American, Western European, and Japanese contexts, which is why there is a need to delve more into the comic-based construction of political discourse in other regions such as Southeast Asia.

As has been argued, however, scholars of Southeast Asian Studies must also look at comics as objects and sites of political discourse instead of mere instruments for the advancement of political interests, although this also cannot be denied in some cases in which 
governments use comics to raise the awareness of the public on certain issues. Nevertheless, it is quite important for scholars to dig deeper into the intimate and discursive relationship between texts and images by taking into account the key events and narratives which have been included and excluded from the flow of the whole story. With the wealth of many other unexplored issues in the region that have been portrayed in comic and other visual forms, Southeast Asian Studies scholars may benefit from an abundance of rich cultural medium to engage in other pressing political issues.

\section{Acknowledgement}

An earlier version of this paper was presented with a scholarship grant from the International Academic Forum (IAFOR) as part of the 2019 Asian Conference on Arts and Humanities (ACAH) held March 29-31, 2019 in Tokyo, Japan. The author would like to thank the discussants and audiences in the said conference for questions, criticisms, and suggestions. He is also extremely grateful for the useful comments of the two anonymous reviewers, but he bears responsibility for all the views expressed here.

\section{References}

Ahmed, F. and Griffiths, J. (2017, September 9). Protests across Asia over Myanmar's treatment of Rohingya Muslims. Cable News Network. Retrieved from www. edition.cnn.com/2017/09/08/asia/ myanmar-rohingya-bangladeshdhaka/index.html

Anderson, Benedict. (1990). Language and power: Exploring political cultures in Indonesia. New York, NY: Cornell University Press.

Associated Press. (2012, June 12) Burma ethnic violence escalates as villagers flee. The Guardian. Retrieved from www.theguardian. com/world/2012/jun/12/burmaethnic-violence-escalates

Agence France-Presse. (2014, July 14). Why is there communal violence in Myanmar?. British Broadcasting Corporation. Retrieved from www.bbc.com/news/worldasia-18395788

Agence France-Presse. (2018, January 25). How Aung San Suu Kyi sees the Rohingya crisis. British Broadcasting Corporation. Retrieved from www.bbc. com/news/world-asia-42824778

Arukesamy, K. (2015, April 16). Refugees not welcome here - Shahidan. The Sun Daily. Retrieved from www. 
thesundaily.my/archive/1387061DSARCH305167

BBC. (2013, August 25). Burma violence: Rioters burn Muslim homes and shops. British Broadcasting Corporation. Retrieved from https:// www.bbc.com/news/worldasia-23831382

Berndt, J. (2014). Studying comics from Southeast Asia. Kyoto University Review of Southeast Asia 16(2). Retrieved from www.kyotoreview. org/issue-16/studying-comicsfrom-southeast-asia/

Brooten, L., Syed I.A., and Akinro, N.A. (2015). Traumatized victims and mutilated bodies: Human rights and the 'politics of immediation' in the Rohingya crisis of Burma/Myanmar. International Communication Gazette 77 (8): 717-734.

Brooten, L. (2014). Political cartoons and Burman's transnational public sphere. In J Lent (Ed.), Southeast Asian Cartoon Art: History, Trends and Problems (pp. 178-204). Jefferson, North Carolina: McFarland.

Buzan, B., Ole, W., and Wilde, J. (1998). Security: A new framework for analysis. Boulder, CO: Lynne Rienner.

Chua, K. (2014). Philippine educational komiks: Shifting perspectives. Kyoto
Review of Southeast Asia 16(2). Retrieved from www.kyotoreview. org/issue-16/educational-komiksshifting-perspectives/

Donnelly, F. (2017). In the name of (de)securitization: Speaking security to protect migrants, refugees and internally displaced persons?. International Review of the Red Cross 99(1), 241-261.

Ellis-Petersen, H. and Arnold, K. (2018, March 21). Htin Kyaw, Myanmar president and Aung San Suu Kyi confidante resigns. The Guardian. Retrieved from www.theguardian. $\mathrm{com} / \mathrm{world} / 2018 / \mathrm{mar} / 21 /$ myanmar-president-aung-san-suukyi-confidante-resigns-htin-kyaw First Look Media. (n.d.) About. Retrieved from www.firstlook. media/about

Frayer, K. (2017, October 15). Desperate journeys: Behind the most haunting images of the Rohingya exodus. Time Magazine. Retrieved from www.time.com/rohingya-exodusmyanmar-refugees-kevin-frayer/

Frayn, R. (2011, December 11). The untold love story of Burma's Aung San Suu Kyi. The Telegraph UK. Retrieved from www.telegraph. co.uk/news/worldnews/asia/ 
burmamyanmar/8948018/Theuntold-love-story-of-Burmas-AungSan-Suu-Kyi.html

Hansen, L. (2015). How images make world politics: International icons and the xase of Abu Ghraib. Review of International Studies 41(2), 263-288.

Hansen, L. (2017). Reading comics for the field of International Relations: Theory, method and the Bosnian War. European Journal of International Relations 23(3), 581-608.

Hansen, L. (2018). Images and international security. In A. Gheciu and W. C. Wohlforth (Eds.), The Oxford Handbook of International Security (pp. 593-606). Oxford: Oxford University Press.

Humphrey, A. (2018). Emotion and secrecy in Australian asylumseeker comics: The politics of visual style. International Journal of Cultural Studies, 21(5), 457-485.

Jati, I. (2017). Comparative study of the roles of ASEAN and the organization of Islamic cooperation in responding to the Rohingya crisis. IKAT: The Indonesian Journal of Southeast Asian Studies 1(1), 17-32.

Kneebone, S. (2016). Comparative regional protection frameworks for Refugees: Norms and norm entrepreneurs. International Journal of Human Rights, 20(2), 153-172.

Lent,J. (2007). SoutheastAsian cartooning: An overview. SPAFA Journal (Old series 1991-2013) 17(1), 7-12.

Lent, J. (2014). Southeast Asian cartoon art: History, trends and problems. Efferson, NC: McFarland.

MacDonald, F., Dodds, K. and Hughes, R. (2010) Observant States: Geopolitics and Visual Culture. London, United Kingdom: I.B. Tauris.

Mironova, V. and Sergatskova, E. (2017, September 22). "Will former ISIS fighters help the Rohingya?. Foreign Affairs. Retrieved from www. foreignaffairs.com/articles/burmamyanmar/2017-09-22/will-formerisis-fighters-help-rohingya

Mohajan, K. (2018). History of Rakhine State and the origin of the Rohingya Muslims. IKAT: The Indonesian Journal of Southeast Asian Studies 2(1), 19-46. Murdoch, L. (2017, September 26). Thai plan to push back Rohingya refugees sparks fears of new wave of Boat People. The Sydney Morning Herald. Retrieved from www.smh. com.au/world/thai-plan-to-pushback-rohingya-refugees-sparksfears-of-new-wave-of-boatpeople-20170926-gyou16.html 
National Post. (2015, May 14). 'We have heen very nice' but Malaysia and Thailand fed up with Boat People and just turned away another 800. National Post. Retrieved from www. nationalpost.com/news/world/wehave-been-very-nice-but-malaysiaand-thailand-fed-up-with-boatpeople-and-just-turned-awayanother-800

Phasuk, S. (2017, September 22). Stop inhumane navy push-backs. The Bangkok Post. Retrieved from www.bangkokpost.com/opinion/ opinion/1328975/stop-inhumanenavy-push-backs

Phuc, N. (2014). Comics in Vietnam: A newly emerging form of storytelling. Kyoto Review of Southeast Asia 16(2). Retrieved from kyotoreview. org/issue-16/comics-in-vietnama-newly-emerging-form-ofstorytelling/

Sani, I., Abdullah, M. H., Abdullah, F. S., \& Ali, A. M. (2012). Political cartoons as a vehicle of setting social agenda: The newspaper wxample. Asian Social Science, 8(6), 156-164.

Shim, D. (2017). Sketching geopolitics: Comics and the case of the Cheonan sinking. International Political Sociology 11(4), 398-417.
Sihombing, F. (2014). Blurring the boundaries of comics classification in Indonesia through Wanara. Kyoto Review of Southeast Asia 16(2). Retrieved from www.kyotoreview. org/issue-16/blurring-theboundaries-of-comics-classificationin-indonesia-through-wanara/

The Daily Star. (2017, December). 114 international organisations, 32 individuals urge Myanmar to protect civilians' rights in Rakhine. The Daily Star. Retrieved from www. thedailystar.net/rohingya-crisis/114international-organisations-32individuals-urge-myanmar-toprotect-civilians-rights-1505050 The Nib. (n.d.). About The Nib. Retrieved from www.thenib.com/about

The Strait Times. (2016, January 12). Aung San Suu Kyi vows to lead peace efforts in speech to Myanmar ethnic armed groups. Agence France-Presse. Retrieved from www. straitstimes.com/asia/se-asia/aungsan-suu-kyi-vows-to-lead-peaceefforts-in-speech-to-myanmarethnic-armed-groups

Thurman, E. (2016, August). Myanmar's Rohingya Refugees. The Nib. Retrieved from www.thenib.com/ myanmar-s-rohingya-refugees 
Tju, L. (2014). Current trends in Singapore comics: When autobiography is mainstream. Kyoto Review of Southeast Asia 16(2). Retrieved from www. kyotoreview.org/issue-16/currenttrends-in-singapore-comics-whenautobiography-is-mainstream/

World Bulletin. (2016, May 21). Myanmar votes down 'Rohingya' citizenship verification. Human Rights in ASEAN. Retrieved from www. humanrightsinasean.info/ article/myanmar-votes-down\%E2\%80\%98rohingya\% E2\%80\%99citizenship-verification.html

Vaughn, J. (2009). The unlikely securitizer: Humanitarian organizations and the securitization of indistinctiveness. Security Dialogue, 40(3), 263-285

Yeung, J. and Lenette, C. (2018). Stranded at sea: Photographic representations of the Rohingya in the 2015 Bay of Bengal crisis. The Qualitative Report 23(6), 1301-1313. 